\title{
INTRODUCTION: THE CULTURAL POLITICS OF FOOD AND EATING IN POLAND AND BEYOND
}

\author{
RENATA E. HRYCIUKa , KATARZYNA E. KRÓL ${ }^{\mathrm{b}}$ \\ ${ }^{a}$ INSTITUTE OF ETHNOLOGY AND CULTURAL ANTHROPOLOGY, UNIVERSITY OF WARSAW \\ ${ }^{\mathrm{b}}$ GRADUATE SCHOOL FOR SOCIAL RESEARCH, POLISH ACADEMY OF SCIENCES
}

\begin{abstract}
This special issue of Ethnologia Polona comprises contributions from an international group of scholars who scrutinize the culturally embedded politics of food and foodways in Poland and beyond. The idea for the special issue "The Cultural Politics of Food and Eating in Poland and Beyond" stemmed from discussions and collaborations with academics working in the area of food studies, and with those who use food as a lens to look at different social, cultural and political phenomena. Both groups share a commitment to a critical perspective in the social sciences and humanities, and a need to strengthen this position within international academia.

We developed this special issue around the cultural politics of food and eating in order to highlight the importance of a critical perspective while studying food-related issues. Our aim is to demonstrate both the thematic scope and the theoretical directions present in the contemporary studies produced by scholars working on Poland, as well as Polish researchers working on other regions. The territorial scope of the volume is wide as it features analyses based on abundant ethnographic and historical material from Poland, Belgium, Georgia, Ukraine, Dagestan and Argentina. The volume features contributions from scholars representing different disciplines (anthropology, sociology, social history and cultural studies) based on original research (extended ethnographic fieldwork, archival research and autoethnography) and presenting a clear methodological reflection.
\end{abstract}

\section{FOOD STUDIES IN POLAND. A BRIEF INTRODUCTION}

Since the early 200os, critical food studies has become a burgeoning academic field in Poland. Several academic achievements marked its early beginnings. In 2006 a monograph, Cmentarz i stót. Pogranicze prawostawno-katolickie w Polsce i na Biatorusi (The Graveyard and the Table. The Catholic and Orthodox Borderland in Poland and Belarus) by Justyna Straczuk was published as part of a prestigious series of the Foun-

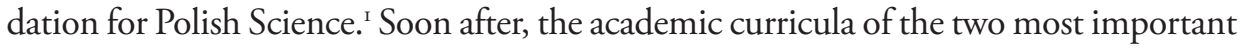

I https://www.fnp.org.pl/en/ (accessed 02.12.2020). 
Polish universities were enriched by courses in new subdisciplines: the anthropology of food conducted since 2008 by Renata E. Hryciuk at the University of Warsaw and the sociology of food taught by Ewa Kopczyńska at the Jagiellonian University since 20IO. The growing interest in this area of the social sciences and humanities has resulted in the first research projects funded by Polish academic institutions (e.g. National Science Centre), including a large multidisciplinary project on changing patterns of food consumption in Poland (see Domański et al. 2015).

Over the last decade, we have also witnessed a substantial increase in publications dealing with food and foodways, of which the following special issues of Polish journals constitute just a selection: Czas Kultury on the politics of taste (2013), Studia Humanistyczne AGH on food fear and distrust (Bachórz, Kopczyńska 2018), Studia Socjologiczne on food and mobility (Bielenin-Lenczowska, Hryciuk, 20I8), Kultura Popularna on food and film (2018) and Revista del CESLA on food heritage (Brulotte and Hryciuk, 2019). In summarising these developments one can say that the scholarship of Polish food research has reflected and developed the recent themes, approaches and methodologies of multidisciplinary and mainly Western food studies (see: Hryciuk and Mroczkowska 20I2, Tierney and Ohnuki-Tierney 20I2, Burnett and Krishnendu 20I2, Murcott 20I6, Hryciuk and Mroczkowska forthcoming).

During this period, an emerging group of scholars interested in critical food studies has been built up in Poland during the nationwide, multidisciplinary seminar "Socio-cultural Contexts of Food Practices" organised between 2013 and 2016 by the Institute of Ethnology and Cultural Anthropology, University of Warsaw, in collaboration with the Institute of Sociology and Philosophy of the Polish Academy of Sciences. ${ }^{2}$ In the wake of weak institutional support for this new and still under-recognized area of study, ${ }^{3}$ an informal Food and Drink Research Network was launched in 2018 by Polish academics and scholars working on food-related topics in Poland. ${ }^{4}$ The establishment of the network is an attempt at setting an agenda for the study of food and consequently for the grassroot institutionalization of a new discipline in

2 The seminar was a collaborative effort of Renata E. Hryciuk (University of Warsaw), Justyna Straczuk (Polish Academy of Sciences), Joanna Mroczkowska (Polish Academy of Sciences) and Zofia Boni (University of Adam Mickiewicz in Poznań) During three years, more than thirty scholars presented the results of their food-related research, a part of them was published in a special section "Food and Mobility" of Studia Socjologiczne (Bielenin-Lenczowska, Hryciuk, 2018): https://etnologia.uw.edu.pl/wokol-etnologii/seminaria/seminaria-jedzeniowe (accessed 02.I2.2020).

3 Here two exceptions should be noted: The Research Centre for Food History and Culture established by Jarosław Dumanowski at Nicolaus Copernicus University and the post-graduate food studies program at the private Warsaw based University of Social Sciences and Humanities (SWPS) https://www.swps.pl/oferta/warszawa/podyplomowe/rozwoj-osobisty-coaching/food-studies (accessed 02.12.2020).

4 https://jedzeniesiecbadawcza.blogspot.com/ (accessed 02.12.2020). 
Poland. For the time being, the Network holds regular meetings and (on-line) seminars. Some of the papers published in this issue have their roots in discussions held at the Network's meetings.

The papers gathered in this thematic issue of Ethnologia Polona present a diverse panorama of critical food studies in Poland. It contributes to ongoing methodological debates by scrutinizing the power relations in international food research (Bachórz and Paresecoli on positionality). It offers an insightful intersectional reading of the relation between food and migration (Urbańska on transnational maternal foodways and Bodzan on female refugees cooking for Warsaw culinary tourists), of gendered foodways in (post)socialist contexts (Stańczak-Wislicz on food habits and socialist modernization in post-war Poland and Król on factory tea production in Georgia), as well as of issues related to the ethics of eating and alternative food networks (Grasseni and Gracjasz on Food not Bombs and Food Banks in Gdańsk). Moreover, this multidisciplinary collection of articles engages in contemporary theoretical debates (among others in this volume Kołodziejska and Kujawska on the edibility approach in ethnobotany) and proposes new theoretical concepts (Urbańska’s "maternal bustling around foodways").

\section{STRUCTURE OF THE SPECIAL SECTION}

The opening essay of the current volume, "Why Should We Care? Two Experiences in the Politics of Food and Food Research", deals with the cultural politics of doing food research by scholars with different positionalities within global academia. Polish sociologist, Agata Bachórz, and American food researcher and journalist, Fabio Parasecoli, provide an auto-ethnographic and reflexive account of a collaboration in an ethnographic and media study about the revaluation of traditional and regional food in Poland among urban middle classes. Their analysis raises questions about the authors' positionalities and the crucial role that these play in their research dynamics, and about the legitimacy of issues related to the study of food within academia and to scholars' engagement outside it.

The politics of food provides an axis of analysis for the next papers presented in this volume. The first is "The Cultural Politics of Food Gifting in Gdańsk. Between Food Not Bombs and Food Banks" by Aleksandra Gracjasz and Cristina Grasseni. Building on ethnographic fieldwork carried out by Gracjasz, the authors look at the re-invention of "food waste" in steadily gentrifying Gdańsk (northern Poland). Using a methodological framework designed for the comparative analysis of collective food procurement in European post-industrial cities, the paper analyses two food gifting initiatives that, despite their superficial similarities - they both give food - embody quite different socio-cultural logics. On the one hand are Food Banks, which are 
embedded in a logic of market transactions (under the guise of gift-giving) and thus strengthen the cultural politics of the market. On the other is the Food Not Bombs movement, which aims at unmaking those market transactions through the act of giving away food and in so doing proposing an a-hierarchical and egalitarian logic of commensality. The comparison of these two cases shows the assumptions about citizenship and solidarity that are inscribed in each.

The act of commensality - of eating and drinking together - is one of the fundamental social activities. Building on ethnographic fieldwork in Warsaw, Magda Bodzan in "Cooking with Refugees and Migrants: Staging Authenticity and Traditionality for Warsaw's Culinary Tourists" offers a nuanced analysis of culinary workshops organised on behalf of refugees and migrants after the migrant crisis in 20I5. Appealing to middle class Warsaw culinary tourists, such workshops create twofold effects. First, they build a space of empowerment for migrants through an embracing of their home country culinary culture. At the same time however, they offer simplified and folklorized representations of these cultures. Bodzan shows the strategies of recreating the "traditionality" of food that are employed by female refugees to authenticate their migration stories and reveals how these women play with commodified expectations concerning their ethnicity and experiences. She also looks at the ways in which migrants and refugees skilfully adapt to the ethical expectations of Warsaw's culinary tourists by creating hybrid, frequently vegetarian forms of dishes. Building on notions of "food capital" and "refugee capital", Bodzan shows how ideas that the host society and the "Other" have about each other are interwoven, reinforced or challenged.

The intersection of migration and foodways is also tackled by Sylwia Urbańska in her paper entitled "Weapons of the Weak Twisted in Jars of Love. Transnational Maternal Foodways of Polish Migrants in Brussels". Here, building on the results of extensive ethnographic fieldwork in both rural Poland and Brussels, and on the journeys in between, she looks at the practices of care employed by Polish working class women immigrants who left their families behind. Urbańska offers a contribution to the study of migration and gendered care practices by showing the development of a postmodern working class motherhood. The author demonstrates how women have to bargain with the expectations posed by patriarchy in order to preserve the rights to motherhood while being a part of a global labour force. When looking at transnational care through food-work, the author suggests that the theoretical frameworks of "long-distance/transnational maternal foodways" should be employed to analyse the experiences of the interviewed women. She suggests enriching the conceptualization of the food related practices of Polish migrants with the concept of a "maternal bustling around foodways". Urbańska sees this both as a strategy of unbecoming a mother and as a coping strategy against neoliberal mechanisms of violence.

Experiences of working class women are also reflected in the paper, "We Have All Lived and Breathed Tea": Gendered Spaces of Factory Tea Production in Western 
Georgia”, by Katarzyna E. Król. Building on material gathered during extensive ethnographic fieldwork, the author focuses on the understudied issue of public spaces of industrial food production, with a focus on female labour in post-socialist Georgia. Król shifts anthropological interest from Georgian hospitality and "traditional" consumption practices, and looks at the production of a commodity which is not widely considered a legitimate part of Georgian foodways. Nevertheless, as the author claims, it is a commodity that has shaped both the landscape and the life-scapes of a substantial number of people, turning tea production into an agent re-organizing the life of whole regions in Georgia. The collapse of the Soviet Union resulted in yet another re-organization of the infrastructure, markets and most importantly lives of tea workers. This paper looks at the gender regime and the contemporary position of female workers at the factory. Similarly to Urbańska, Król approaches the problem of working class female migrants struggling to adhere to or resist patriarchal ideals of womanhood.

The following paper, "The Edibility Approach, Chemical Ecology and Relationality: Methodological and Ethnobotanical Contributions", by Iwa Kołodziejska and Monika Kujawska combines ethnographic and ethnobotanical fieldwork. The authors argue for the expansion of the edibility approach (EA) in order to give more attention to cross-species interactions between humans and not cultivated wild plants placed in an environmental context. Based on rich material gathered in three different cultural settings and ecosystems (Dagestan, Eastern Podilia in Ukraine and the Atlantic Forest of Argentina), this paper advocates incorporating Inglot's idea of dwelling and chemical ecology into the edibility approach as a potentially fruitful methodology for the analysis of multispecies entanglements. The text includes a call for closer collaboration between anthropologists, ethnobotanists, ecologists and chemical ecologists in this type of studies.

The final article in this volume, "Eating Healthy, Eating Modern: The "Urbanization" of Food Tastes in Communist Poland (1945-1989)", by the social historian Katarzyna Stańczak-Wiślicz focuses on the changing meaning of food and its role in the process of socialist modernization in post-war Poland. The communist project of modernization included changes of food habits based on "science and reason": therefore, extensive efforts were made to establish special institutions and agendas providing expert knowledge. The author shows the role of dietary education in governing and feeding the nation. Building on a variety of archival sources (women's magazines, medical literature and personal narratives), Stańczak-Wiślicz challenges the perception of the period after 1945 as a monolithic era, both in terms of official food policies and people's responses to them. Instead, Stańczak-Wiślicz shows how fluid and dependent on the political situation in the country was the definition of "traditional": from being labelled as backward and unhealthy in the first years after the war to a sudden rehabilitation during the crisis of the 1980 os, which brought a renewed appreciation of "simple and natural" recipes. 
This special issue concludes with a review by Karolina Bielenin-Lenczowska of the monograph Balkan Blues. Consumer Politics after State Socialism published in 2019 by the Korean-American anthropologist Yuson Jung. Based on the results of extensive ethnographic fieldwork in Bulgaria, Jung analyses the everyday consumer practices and strategies of impoverished inhabitants of the capital city in one of the poorest post-socialist states of the European Union. The author looks at inequality in access to goods, the pursuit of consumer rights and, more broadly, consumption as a site of civic engagement. The bookl also includes an informative appendix on fieldwork methodology and the positionality of an East Asian researcher in the Balkans. In her final remarks, Bielenin-Lenczowska stresses that the book proves the concept of post-socialism to still be a useful and effective analytical tool, not only in the context of Central and Eastern Europe, but also in the Balkans.

We believe that the present volume will be of interest both to the growing food studies community and to a wider audience of those interested in the deeper social and cultural repercussions of food related practices. We hope that both groups of readers will find in the journal an informative and inspiring collection of articles.

\section{REFERENCES}

Bachórz, Agata, and Ewa Kopczyńska. 2018. "Food fear, food distrust and food exclusion in one postsocialist society and beyond." Studia Humanistyczne AGH I7 (2), 7-I3.

Bielenin-Lenczowska, Karolina, and Renata E. Hryciuk. 20ı8. Jedzenie i mobilność w perspektywie antropologicznej. Wprowadzenie. [Anthropology of food and mobility. An introduction] Studia Socjologiczne 4 (23I), 75-76.

Brulotte, Ronda, and Renata E. Hryciuk. 2019. "Critical approaches to food heritage in Latin America. An Introduction.” Revista del CESLA. International Latin American Studies Review 24, I-5.

Burnett, Sierra Clark, and Ray Krishnendu. 2012. "Sociology of food." In The Oxford Handbook of Food History, edited by Jeffrey M. Pilcher, Oxford: Oxford University Press, I35-I53.

Domański, Henryk, and Zbigniew Karpiński, and Dariusz Przybysz, and Justyna Straczuk. eds. 2015. Wzory jedzenia a struktura spoteczna [Food Patterns and Social Structure]: Wydawnictwo Naukowe Scholar.

Hryciuk, Renata E., and Joanna, Mroczkowska. 20I2. "Co Wy tam gotujecie? O antropologicznych badaniach nad jedzeniem" ["And what are you cooking there?": On anthropological food studies], (op.cit.) $43,3-7$.

Hryciuk, Renata E., and Joanna Mroczkowska. forthcoming. „Introduction.” In: Jedzenie. Perspektywa antropologiczna, (Post)socjalizm [Food. Anthropological perspective, (post)socialism], edited by Renata E. Hryciuk and Joanna Mroczkowska, Warsaw University Press.

Murcott, Anne. 2016. "A Burgeoning Field: Introduction to The Handbook of Food Research.” In: The Handbook of Food Research, edited by Anne Murcott and Warren Belasco and Peter Jackson London: Bloomsbury. 
Straczuk, Justyna. 2006. Cmentarz i stót. Pogranicze prawostawno-katolickie w Polsce i na Biatorusi, [The Graveyard and the Table. The catholic and orthodox borderland in Poland and Bielarus] Wrocław: Monografie FNP.

Tierney R. Kenji, and Emiko Ohnuki-Tierney. 20I2. "Anthropology of Food.” In: The Oxford Handbook of Food History, edited by Jeffrey M. Pilcher, Oxford: Oxford University Press: II7-I34.

\section{GUEST EDITORS' CONTACTS:}

Renata E. Hryciuk

Institute of Ethnology and Cultural Anthropology, University of Warsaw

e-mail: r.hryciuk@uw.edu.pl

ORCID: 0000-0002-6740-05I4

Katarzyna E. Król

Graduate School for Social Research, Polish Academy of Sciences

e-mail:kkrol@ifispan.edu.pl

ORCID: 0000-0002-II3I-8247

(c) 